\title{
Association between Inter-Limb Asymmetries in Lower-Limb Functional Performance and Sport Injury: A Systematic Review of Prospective Cohort Studies
}

\author{
Yanfei Guan ${ }^{1}$, Shannon S. D. Bredin ${ }^{1}$, Jack Taunton ${ }^{2}$, Qinxian Jiang ${ }^{3}$, Nana Wu ${ }^{1}$ D \\ and Darren E. R. Warburton 1,4,*(D)
}

Citation: Guan, Y.; Bredin, S.S.D.; Taunton, J.; Jiang, Q.; Wu, N.;

Warburton, D.E.R. Association between Inter-Limb Asymmetries in Lower-Limb Functional Performance and Sport Injury: A Systematic Review of Prospective Cohort Studies. J. Clin. Med. 2022, 11, 360. https://doi.org/10.3390/ jcm 11020360

Academic Editors: Bernhard Rauch and Gregory Y. H. Lip

Received: 30 October 2021

Accepted: 9 January 2022

Published: 12 January 2022

Publisher's Note: MDPI stays neutral with regard to jurisdictional claims in published maps and institutional affiliations.

Copyright: (C) 2022 by the authors. Licensee MDPI, Basel, Switzerland. This article is an open access article distributed under the terms and conditions of the Creative Commons Attribution (CC BY) license (https:// creativecommons.org/licenses/by/ $4.0 /$ )
1 Physical Activity Promotion and Chronic Disease Prevention Unit, Faculty of Education, School of Kinesiology, University of British Columbia, Vancouver, BC V6T 1Z4, Canada; yanfei.guan@ubc.ca (Y.G.); shannon.bredin@ubc.ca (S.S.D.B.); nana.wu@ubc.ca (N.W.)

2 Allan McGavin Sport Medicine Centre, Faculty of Medicine, University of British Columbia, Vancouver, BC V6T 1Z3, Canada; jack.taunton@ubc.ca

3 Department of Physical Education, Weifang Medical University, Weifang 261053, China; qinxian.jiang@wfmc.edu.cn

4 Experimental Medicine Program, Faculty of Medicine, University of British Columbia, Vancouver, BC V6T 1Z4, Canada

* Correspondence: darren.warburton@ubc.ca; Tel.: +1-604-822-4603

\begin{abstract}
Background: Inter-limb asymmetry in lower-limb functional performance has been associated with increased risk of sport injury; however, findings are not always consistent. Purpose: To conduct a systematic review on whether inter-limb asymmetry in lower-limb functional performance can predict sport injury. Methods: Four electronic databases (MEDLINE, EMBASE, Web of Science, and SportDiscus) were systematically searched for prospective cohort studies reporting the association between inter-limb asymmetry in lower-limb functional performance and sport injury. Results: A total of 28 prospective cohort studies were included in the analyses. Collectively, the findings were highly inconsistent, and a clear statement on the association between each asymmetry and sport injury was difficult. Conclusions: Highly inconsistent findings make it difficult to create clear recommendations on the relationship between the inter-limb asymmetry in lower-limb functional performance (power, muscle flexibility, and dynamic balance) and sport injury. The influence of potential factors (selection of tests/parameters, participant characteristics, definition of injury, and ways of calculating asymmetry) should be considered when using previous findings.
\end{abstract}

Keywords: sport injury; lower-limb asymmetry; functional performance; injury prediction

\section{Introduction}

Inter-limb asymmetry refers to the difference between the two sides of limbs [1,2]. There is growing attention on the association between inter-limb asymmetry in lower-limb functional performance and sport injury [3,4]. Inter-limb asymmetry may potentially place both legs at an increased risk of injury in sports; the strong leg may sustain excessive stress due to high dependence and loading, whereas the weak leg may be compromised to sustain even average load [5]. In addition, inter-limb asymmetries have been associated with increased risk of sport injury because the asymmetries may result in unequal force absorption or a loss of frontal plane stability, which are important to sustain the impacting forces [6].

To date, the validity of using inter-limb asymmetries in lower-limb strength/power and dynamic balance to predict sport injury has been widely investigated. The lower-limb strength/power has commonly been assessed with jump tests and isometric/isokinetic strength tests. A $\geq 15 \%$ inter-limb asymmetry in lower-limb strength/power has been associated with greater risk of sport injury [3,7]. Dynamic balance has usually been assessed 
with the star excursion balance test (SEBT) originally developed by Gray [8] and its modified version ( $Y$ balance test). It has been reported that $\geq 4 \mathrm{~cm}$ inter-limb asymmetry in anterior reach distance in the SEBT [4] and Y balance test [9] indicates increased risk of sport injury. However, there are also a number of studies demonstrating no association between sport injury and inter-limb asymmetry in lower-limb strength/power $[10,11]$ or dynamic balance (measured with the SEBT or Y balance test) [12,13]. In addition, a few studies have also examined the association between inter-limb asymmetry in lower-limb muscle flexibility and sport injury $[3,14,15]$, and the findings were also inconsistent. Due to the high inconsistency of findings in the literature, it is difficult to draw a conclusion about the validity of using inter-limb asymmetry in lower-limb functional performance for injury prediction.

Systematically synthesizing the results in the current literature and analyzing the factors contributing to the inconsistency of findings is essential; however, a systematic overview and discussion on previous findings is missing to date. Therefore, the aim of this study was to systematically review the prospective cohort studies examining whether interlimb asymmetry in lower-limb functional performance (strength/power, dynamic balance, and muscle flexibility) can predict sport injury. The findings of this systematic review will provide a better understanding of the association between inter-limb asymmetry in lower-limb functional performance and sport injury, and guide future research and practical application.

\section{Method}

\subsection{Literature Search}

A systematic literature search was conducted in April 2021 to identify relevant trials. The search was performed in four databases: MEDLINE, EMBASE, Web of Science, and SportDiscus. An individualized search strategy was designed for each database. The search results from different databases were combined, and duplicates were removed. The titles and abstracts of the remaining articles were then independently checked by two authors (Y.G. and N.W.), and unrelated publications were removed. Afterward, both authors independently evaluated the full text of the remaining articles for inclusion. Finally, reference lists of the included articles were manually checked by the two authors for additional studies that were suitable for the present systematic review. Any discrepancy was resolved by consensus, or by discussion with the third reviewer (Q.J.). The process was overseen by a university professor with expertise in systematic reviews and knowledge mobilization (S.B.). The search process is demonstrated in Figure 1. The entire process adhered to the standards established by the Preferred Reporting Items for Systematic Reviews and Meta-Analyses (PRISMA) recommendations [16].

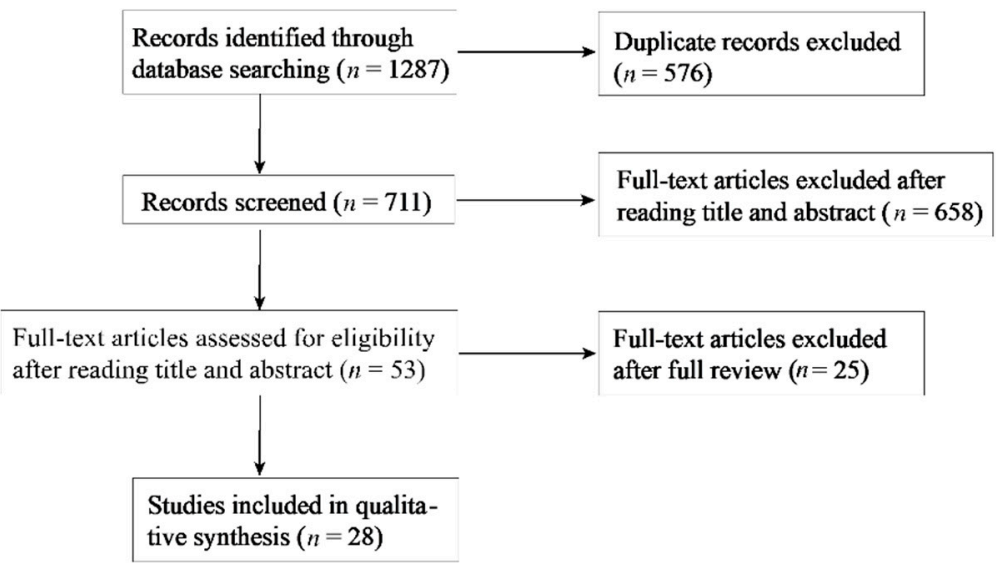

Figure 1. Flowchart of the search process. 


\subsection{Inclusion and Exclusion Criteria}

Inclusion criteria required studies with a prospective cohort design (with a baseline test and prospective follow-up) to examine the effects of inter-limb asymmetries in lowerlimb power/strength, dynamic balance, or lower-limb muscle flexibility on risk of sport injury. Studies focusing on side-to-side asymmetry in upper-limb or trunk were excluded. Studies only reported inter-limb asymmetry without examining the association with sport injury were excluded. Studies focusing on the effects of injury on asymmetries, or the relationship between asymmetries and previous injuries were excluded. Reviews and articles not published in English were also excluded. No restrictions were imposed based on the year of publication.

\subsection{Data extraction and Analyses}

The core features of the included studies were extracted, including participant characteristics, tests / tasks used for assessing inter-limb asymmetries, definition of injury, duration of follow-up, outcome measurements, equations for quantifying asymmetries, and results.

\subsection{Study Quality}

A quality assessment (Table 1) was conducted using the Newcastle-Ottawa Scale designed for cohort studies [17]. Each study was assessed on eight items categorizing into three sections: selection (4 items), comparability (1 item), and outcome ( 3 items). A study can be awarded a maximum of one star for each item under the section of selection and outcome; a maximum of two stars can be awarded to a study under the section of comparability [17]. All included studies were assessed with good ( 3 or 4 stars in selection AND 1 or 2 stars in comparability AND 2 or 3 stars in outcome) or fair (2 stars in selection AND 1 or 2 stars in comparability AND 2 or 2 stars in outcome) quality.

Table 1. Study quality assessment with the Newcastle-Ottawa Scale.

\begin{tabular}{|c|c|c|c|}
\hline & Selection & Comparability & Outcome \\
\hline Brumitt, Heiderscheit, Manske et al. [18] & 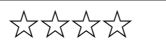 & $\dot{s}$ & 金主 \\
\hline Brumitt, Mattocks, Loew and Lentz [10] & 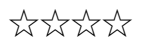 & $\hat{s}$ & $\hat{\imath} \boldsymbol{s}$ \\
\hline Brumitt, Nelson, Duey, et al. [13] & 它方 & $\hat{s}$ & 它地 \\
\hline Brumitt, Sikkema, Mair et al. [19] & 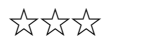 & $\hat{s}$ & $\hat{i} \boldsymbol{s}$ \\
\hline Butler, Lehr, Fink et al. [20] & 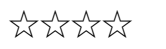 & 它众 & 它动方 \\
\hline De Blaiser, Roosen, Willems et al. [21] & tsis & 柁 & 功论 \\
\hline Fousekis, Tsepis, Poulmedis, et al. [14] & 它去 & $\hat{s}$ & 它地 \\
\hline Fousekis, Tsepis and Vagenas [15] & 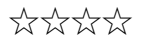 & $\hat{\imath} \boldsymbol{2}$ & 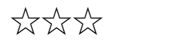 \\
\hline $\begin{array}{l}\text { Fort-Vanmeerhaeghe, Mila-Villarroel, } \\
\text { Pujol-Marzo et al. [22] }\end{array}$ & 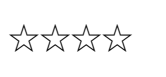 & $\hat{s}$ & 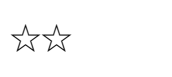 \\
\hline Gonell, Romero and Soler [23] & 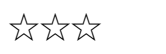 & $\hat{x} \boldsymbol{x}$ & 必放 \\
\hline Hartley, Hoch and Boling [24] & 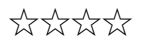 & $\hat{s} \boldsymbol{s}$ & $\hat{\imath} \boldsymbol{s}$ \\
\hline Hietamo, Pasanen, Leppänen et al. [25] & 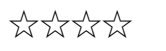 & $\hat{i} \hat{s}$ & 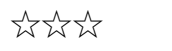 \\
\hline Knapik, Bauman, Jones, et al. [3] & 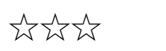 & 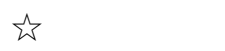 & 必放 \\
\hline Lai, Wang, Chen et al. [26] & 象金方 & $\hat{z} \boldsymbol{s}$ & 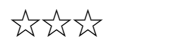 \\
\hline Lisman, Hildebrand, Nadelen and Leppert [12] & 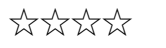 & 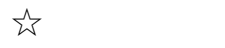 & $\hat{i} \boldsymbol{2}$ \\
\hline Luedke, Geisthardt and Rauh [27] & 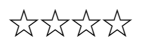 & $\hat{s}$ & 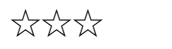 \\
\hline Manoel, Xixirry, Soeira et al. [28] & 象金象 & 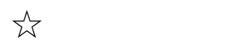 & 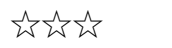 \\
\hline Markovic, Šarabon, Pausic and Hadžić [11] & 它地方 & $\hat{i} \hat{s}$ & 它地 \\
\hline Nakagawa, dos Santos, Lessi et al. [29] & 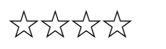 & 它全 & 它地 \\
\hline Paterno, Schmitt, Ford, et al. [6] & 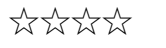 & 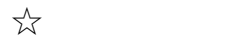 & $\hat{i} \hat{2}$ \\
\hline Plisky, Rauh, Kaminski and Underwood [4] & 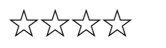 & $\dot{s}$ & 文方金 \\
\hline Read, Oliver, Myer et al. [30] & 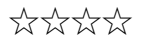 & $\hat{t} \hat{2}$ & $\hat{z} \sum \hat{z}$ \\
\hline Read, Oliver, Croix et al. [31] & 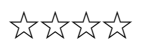 & 幽出 & 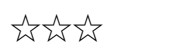 \\
\hline
\end{tabular}


Table 1. Cont.

\begin{tabular}{|c|c|c|c|}
\hline & Selection & Comparability & Outcome \\
\hline Ruffe, Sorce, Rosenthal and Rauh [32] & 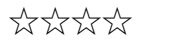 & 象弥 & 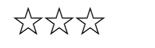 \\
\hline Sieland, Krause, Kalo et al. [33] & 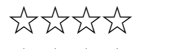 & $\sum$ & 必市 \\
\hline Smith, Chimera and Warren [9] & 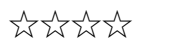 & 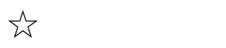 & 象金方 \\
\hline Steidl-Muller, Hildebrandt, Muller et al. [34] & 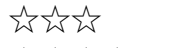 & $\sum$ 约 & $\hat{i} \hat{s}$ \\
\hline Warren, Lininger, Smith et al. [35] & 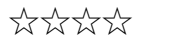 & 必坛 & 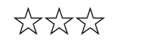 \\
\hline
\end{tabular}

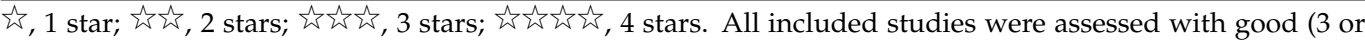
4 stars in selection AND 1 or 2 stars in comparability AND 2 or 3 stars in outcome) or fair (2 stars in selection AND 1 or 2 stars in comparability AND 2 or 2 stars in outcome) quality.

\section{Results}

\subsection{Search Results}

A total of 28 studies were included in the analyses. Fourteen studies reported the association between inter-limb asymmetries in lower-limb power/strength and sport injury; three studies reported the association between inter-limb asymmetries in lower-limb muscle flexibility and sport injury; fifteen studies reported the association between inter-limb asymmetries in dynamic balance and sport injury. Studies examining inter-limb asymmetries in multiple tasks may be counted twice or more.

\subsection{Participant Characteristics}

Eleven studies included both males and females; three studies only included females, and 12 studies only included males; two studies did not present information about the sex of the participants. Concerning the age of participants, most studies included adult athletes, and only four studies focused on pediatric-age athletes ( $\leq 17$ years); four studies included both pediatric-age and adult athletes without separating them for analyses.

All studies included participants with a sporting background. In studies focusing on adult athletes, four included professional soccer athletes, 11 included collegiate athletes from a range of sports, one included collegiate students majored in physical education, and one included military recruits. Among the four studies focusing on pediatric-age athletes, one included handball, volleyball, and basketball athletes, two included soccer athletes, and one included ski racers. Only one study included athletes who had ACL reconstruction and returned to sport; all the other studies included healthy athletes. The number of participants in a study ranged from 45 to 362 .

\subsection{Tests and Outcome Measurements}

The characteristics of the 14 studies focusing on lower-limb strength/power are listed in Table 2. Seven studies examined inter-limb asymmetries in unilateral jumps, including single-leg CMJ, hop, triple hop, and crossover hop. Outcome measurements included the vertical height and the kinetics (e.g., peak vertical ground reaction force) of the singleleg CMJ, and the horizontal distance of the hops. One study examined the inter-limb asymmetries in biomechanics in the bilateral drop vertical jump. In addition to the jump tests, there are also studies examining the inter-limb asymmetry in lower-limb strength with isometric ( 5 studies) and isokinetic (5 studies) strength tests. Outcome measurements included the peak force in isometric and isokinetic knee extension [34], normalized (to body mass) peak force in isometric hip adduction and abduction, hip external and internal rotation, and hip flexion and extension [21], normalized (to body mass) peak torque in isokinetic knee flexion and isometric hip abduction [25], peak torque in isometric hip adduction [11], peak torque in isokinetic knee extension and flexion, ankle plantar flexion and dorsal flexion [14], peak torque in isokinetic dorsal flexion and plantar flexion [15], and peak torque in isokinetic knee flexion and extension [3]. 
Table 2. Study characteristics—inter-limb asymmetries in lower-limb strength/power and muscle flexibility.

\begin{tabular}{|c|c|c|c|c|c|}
\hline References & Participants & $\begin{array}{l}\text { Tasks and Outcome } \\
\text { Measures }\end{array}$ & Injury & $\begin{array}{l}\text { Duration of } \\
\text { Follow-Up }\end{array}$ & $\begin{array}{l}\text { Quality } \\
\text { Score }\end{array}$ \\
\hline Brumitt, Heiderscheit, Manske, et al. [18] & 193 collegiate athletes & Single-leg hop distance & $\begin{array}{l}\text { Low back or lower-limb } \\
\text { injury }(\geq 1 \text {-d time loss) }\end{array}$ & 1 season & 16 \\
\hline Brumitt, Mattocks, Loew and Lentz [10] & $\begin{array}{l}82 \text { female collegiate } \\
\text { volleyball players }\end{array}$ & Single-leg hop distance & $\begin{array}{l}\text { Non-contact injury to } \\
\text { low back or lower limbs } \\
(\geq 1 \text {-d time loss) }\end{array}$ & 1 season & 16 \\
\hline Read, Oliver, Croix, et al. [31] & $\begin{array}{l}357 \text { elite male youth soccer } \\
\text { players (aged } 10-18 \mathrm{y} \text { ) }\end{array}$ & Single-leg CMJ and hop & $\begin{array}{l}\text { Non-contact lower-limb } \\
\text { injury ( } \geq 48 \text {-h time loss) }\end{array}$ & 10 months & 17 \\
\hline $\begin{array}{l}\text { Fort-Vanmeerhaeghe, Mila-Villarroel, } \\
\text { Pujol-Marzo, et al. [22] }\end{array}$ & $\begin{array}{l}81 \text { young elite team-sport } \\
\text { athletes (U14-U18) }\end{array}$ & Single-leg CMJ and hop & Non-contact injury & 1 season & 17 \\
\hline Warren, Lininger, Smith, et al. [35] & $\begin{array}{l}68 \text { female } \\
\text { collegiate athletes }\end{array}$ & $\begin{array}{l}\text { Single-leg hop, } \\
\text { triple-hop, and } \\
\text { crossover distance }\end{array}$ & $\begin{array}{l}\text { Non-contact lower-limb } \\
\text { and spine injury } \\
\text { requiring intervention } \\
\text { by athletic trainer }\end{array}$ & 1 year & 17 \\
\hline Paterno, Schmitt, Ford, et al. [6] & $\begin{array}{l}56 \text { young athletes (aged } \\
16.41 \pm 2.97 \text { y who had } \\
\text { ACL reconstruction and } \\
\text { returned to sport }\end{array}$ & $\begin{array}{l}\text { Bilateral drop } \\
\text { vertical jump }\end{array}$ & Second ACL injury & 1 year & 15 \\
\hline Sieland, Krause, Kalo, et al. [33] & $\begin{array}{l}250 \text { male youth elite soccer } \\
\text { players }(13.5 \pm 4.5 \mathrm{y})\end{array}$ & $\begin{array}{l}\text { Single-leg CMJ and hop, } \\
\text { isometric knee } \\
\text { extension and } \\
\text { flexion strength }\end{array}$ & $\geq 1$-d time loss injury & 2 seasons & 15 \\
\hline Steidl-Muller, Hildebrandt, Muller, et al. [34] & $\begin{array}{l}95 \text { youth }(10-14 \text { y) }, 107 \\
\text { adolescents }(15-19 \text { y), and } \\
83 \text { elite adult }(20-34 \text { y) } \\
\text { ski racers }\end{array}$ & $\begin{array}{l}\text { Single-leg CMJ, } \\
\text { isometric/isokinetic } \\
\text { knee extension strength }\end{array}$ & $\begin{array}{l}\text { Traumatic and overuse } \\
\text { injury ( } \geq 1-\mathrm{d} \text { time loss) }\end{array}$ & 2 seasons & 18 \\
\hline De Blaiser, Roosen, Willems, et al. [21] & $\begin{array}{l}142 \text { collegiate physical } \\
\text { education students }\end{array}$ & Isometric hip strength & $\begin{array}{l}\text { Non-contact, acute } \\
\text { lower-limb injury }\end{array}$ & 1.5 years & 17 \\
\hline Hietamo, Pasanen, Leppänen, et al. [25] & $\begin{array}{l}\text { Team-sport athletes aged } \\
\leq 21 \text { y ( } 188 \text { males, } \\
174 \text { females) }\end{array}$ & $\begin{array}{l}\text { Isokinetic }\left(60^{\circ} / \mathrm{s}\right) \\
\text { quadriceps and } \\
\text { hamstring strength; } \\
\text { isometric hip } \\
\text { abductor strength }\end{array}$ & $\begin{array}{l}\text { Acute ankle injury } \\
(\geq 1-\mathrm{d} \text { time loss })\end{array}$ & 1 year & 16 \\
\hline Markovic, Šarabon, Pausic and Hadžić [11] & $\begin{array}{l}45 \text { professional outfield } \\
\text { male soccer players }\end{array}$ & $\begin{array}{l}\text { Isometric hip } \\
\text { adductor strength }\end{array}$ & Groin injury & 1 season & 18 \\
\hline Fousekis, Tsepis, Poulmedis, et al. [14] & $\begin{array}{l}100 \text { professional male } \\
\text { soccer players }\end{array}$ & $\begin{array}{l}\text { Isokinetic knee strength; } \\
\text { knee and } \\
\text { ankle flexibility }\end{array}$ & $\begin{array}{l}\text { Non-contact hamstrings } \\
\text { and quadriceps strains } \\
(\geq 1 \text {-d time loss) }\end{array}$ & 10 months & 17 \\
\hline Fousekis, Tsepis and Vagenas [15] & $\begin{array}{l}100 \text { professional male } \\
\text { soccer players }\end{array}$ & $\begin{array}{l}\text { Isokinetic }\left(60^{\circ} / \mathrm{s}\right) \text { ankle } \\
\text { strength; } \\
\text { ankle flexibility }\end{array}$ & $\begin{array}{l}\text { Non-contact } \\
\text { ankle sprain }\end{array}$ & 10 months & 17 \\
\hline Knapik, Bauman, Jones, et al. [3] & $\begin{array}{l}138 \text { female } \\
\text { collegiate athletes }\end{array}$ & $\begin{array}{l}\text { Isokinetic ( } 30 \text { and } \\
\left.180^{\circ} / \mathrm{s}\right) \text { knee strength; } \\
\text { ankle, knee, and } \\
\text { hip flexibility }\end{array}$ & Time-loss injury & 1 year & 15 \\
\hline
\end{tabular}

CMJ, single-leg countermovement jump; ACL, anterior cruciate ligament.

Three studies examined the association between inter-limb asymmetries in lower-limb muscle flexibilities and sport injury (Table 2). Outcome measurements included the range of motion $\left(^{\circ}\right)$ in the ankle, knee, and hip measured with a goniometer.

Characteristics of the 15 studies focusing on dynamic balance (measured with the SEBT and $Y$ balance test) are listed in Table 3. Reach distances at the anterior, posteromedial, and posterolateral direction were measured for each leg. Inter-limb asymmetry in reach distance at each direction was calculated. 
Table 3. Study characteristics_-inter-limb asymmetries in dynamic balance.

\begin{tabular}{|c|c|c|c|c|c|}
\hline References & Participants & $\begin{array}{l}\text { Tasks and Outcome } \\
\text { Measures }\end{array}$ & Injury & $\begin{array}{l}\text { Duration of } \\
\text { Follow-Up }\end{array}$ & $\begin{array}{l}\text { Quality } \\
\text { Score }\end{array}$ \\
\hline Brumitt, Nelson, Duey, et al. [13] & $\begin{array}{l}169 \text { male collegiate } \\
\text { basketball players }\end{array}$ & $\begin{array}{l}\text { ANT, PM, PL reach } \\
\text { distance in YBT }\end{array}$ & $\begin{array}{l}\text { Non-contact low-back } \\
\text { or lower-limb injury } \\
\text { ( } \geq 1 \text {-d time loss) }\end{array}$ & 1 season & 15 \\
\hline Brumitt, Sikkema, Mair, et al. [19] & 214 collegiate athletes & $\begin{array}{l}\text { ANT, PM, PL reach } \\
\text { distance in YBT }\end{array}$ & $\begin{array}{l}\text { Non-contact low-back } \\
\text { or lower-limb injury } \\
\text { ( } \geq 1 \text {-d time loss) }\end{array}$ & 1 season & 16 \\
\hline Butler, Lehr, Fink, et al. [20] & $\begin{array}{l}59 \text { collegiate American } \\
\text { football players (males) }\end{array}$ & $\begin{array}{l}\text { ANT, PM, PL reach } \\
\text { distance in YBT }\end{array}$ & $\begin{array}{l}\text { Non-contact lower-limb } \\
\text { injury ( } \geq 1 \text {-d time loss) }\end{array}$ & 1 season & 15 \\
\hline De Blaiser, Roosen, Willems, et al. [21] & $\begin{array}{l}142 \text { physical } \\
\text { education students }\end{array}$ & $\begin{array}{l}\text { ANT, PM, PL reach } \\
\text { distance in SEBT }\end{array}$ & $\begin{array}{l}\text { Non-contact, acute } \\
\text { lower-limb injury }\end{array}$ & 1.5 years & 17 \\
\hline Gonell, Romero and Soler [23] & 74 male soccer players & $\begin{array}{l}\text { ANT, PM, PL reach } \\
\text { distance in YBT }\end{array}$ & $\begin{array}{l}\text { Lower-limb injury } \\
(\geq 1 \text {-d time loss })\end{array}$ & 1 season & 18 \\
\hline Hartley, Hoch and Boling [24] & $\begin{array}{l}\text { Collegiate athletes } \\
(284 \text { males and } \\
167 \text { females })\end{array}$ & $\begin{array}{l}\text { ANT, PM, PL reach } \\
\text { distance in YBT }\end{array}$ & Ankle sprain injury & 2 years & 17 \\
\hline Lai, Wang, Chen, et al. [26] & 294 collegiate athletes & $\begin{array}{l}\text { ANT, PM, PL reach } \\
\text { distance in YBT }\end{array}$ & $\begin{array}{l}\text { Lower-limb injury } \\
\text { ( } \geq 7 \text {-d time loss) }\end{array}$ & 1 season & 16 \\
\hline $\begin{array}{l}\text { Lisman, Hildebrand, Nadelen and } \\
\text { Leppert [12] }\end{array}$ & $\begin{array}{l}124 \text { high-school athletes } \\
\text { (injured group aged } 16.1 \mathrm{y} ; \\
\text { uninjured group aged } \\
15.8 \mathrm{y} \text { ) }\end{array}$ & $\begin{array}{l}\text { ANT, PM, PL reach } \\
\text { distance in YBT }\end{array}$ & $\begin{array}{l}\text { Lower-limb injury } \\
(\geq 1 \text {-d time loss })\end{array}$ & 4 months & 18 \\
\hline Luedke, Geisthardt and Rauh [27] & $\begin{array}{l}59 \text { male collegiate } \\
\text { American football players }\end{array}$ & $\begin{array}{l}\mathrm{ANT}, \mathrm{PM}, \mathrm{PL} \text {, and COM } \\
\text { reach distance in YBT }\end{array}$ & $\begin{array}{l}\text { Non-contact lower-limb } \\
\text { or lower-back injury } \\
\text { ( } \geq 1 \text {-d time loss) }\end{array}$ & 1 season & 17 \\
\hline Manoel, Xixirry, Soeira, et al. [28] & $\begin{array}{l}89 \text { professional male } \\
\text { soccer athletes }\end{array}$ & $\begin{array}{l}\text { ANT, PM, PL reach } \\
\text { distance in YBT }\end{array}$ & Time-loss injury & 1 season & 16 \\
\hline Nakagawa, dos Santos, Lessi, et al. [29] & 135 male military recruits & $\begin{array}{l}\text { ANT, PM, PL reach } \\
\text { distance in YBT }\end{array}$ & Patellofemoral pain & 6 weeks & 17 \\
\hline Plisky, Rauh, Kaminski and Underwood [4] & $\begin{array}{l}235 \text { high-school } \\
\text { basketball players }\end{array}$ & $\begin{array}{l}\text { ANT, PM, PL reach } \\
\text { distance in SEBT }\end{array}$ & $\begin{array}{l}\text { Lower-limb injury } \\
(\geq 1 \text {-d time loss })\end{array}$ & 1 season & 17 \\
\hline Read, Oliver, Myer, et al. [30] & $\begin{array}{l}346 \text { elite male youth soccer } \\
\text { players (age: pre PHV, } \\
11.9 \pm 1.1 \text { y; circa PHV, } \\
14.4 \pm 0.9 \text { y; post PHV, } \\
16.1 \pm 1.1 \text { y) }\end{array}$ & $\begin{array}{l}\text { ANT reach distance } \\
\text { in YBT }\end{array}$ & $\begin{array}{l}\text { Non-contact lower-limb } \\
\text { injury ( } \geq 48 \text {-h time loss) }\end{array}$ & 1 season & 17 \\
\hline Ruffe, Sorce, Rosenthal and Rauh [32] & $\begin{array}{l}148 \text { cross-country athletes } \\
\text { aged between } 13 \text { and } \\
19 \text { years }\end{array}$ & $\begin{array}{l}\text { ANT, PM, PL reach } \\
\text { distance in YBT }\end{array}$ & $\begin{array}{l}\text { Low back or lower-limb } \\
\text { injury ( } \geq 1 \text {-d time loss) }\end{array}$ & 1 season & 16 \\
\hline Smith, Chimera and Warren [9] & 200 collegiate athletes & $\begin{array}{l}\text { ANT, PM, PL reach } \\
\text { distance in YBT }\end{array}$ & Non-contact injury & 1 season & 17 \\
\hline
\end{tabular}

ANT, anterior; PM, posteromedial; PL, posterolateral; YBT, Y balance test; SEBT, star excursion balance test; COM, composite; PHV, peak height velocity.

\subsection{Definition of Injury}

The definition of injury varies across studies due to the difference in mechanism of injury (non-contact vs. contact injury), duration of time loss from sport activities, the included body part of injury, and the duration of follow-up (after the baseline tests). For mechanism of injury, most studies only included non-contact injuries, while some studies included both contact and non-contact injuries. For the body part of injury, most studies focused on lower-limb injuries or injuries occurring to a certain part of the lower extremities (e.g., groin, ankle). In regard to the requirement of time loss, most studies only included injuries leading to time loss from sport participation, and the duration of time loss was usually one day or longer. In addition, the duration of follow-up for collecting information of injury (after the baseline tests) ranged from 1-2 seasons or 10-18 months; however, the specific duration of a season was not always clearly defined.

\subsection{Calculation of Asymmetries}

A variety of equations were employed to calculate the inter-limb asymmetry in lowerlimb power/strength (Table 4). The inter-limb asymmetry was commonly calculated as a percentage of difference between one limb with respect to the other. Six different 
equations were used in eight studies to quantify the inter-limb asymmetry as a percentage. In addition, one study used the absolute difference $(\mathrm{cm})$ in hop distance between the two sides to quantify the inter-limb asymmetry [35]. However, five studies did not present the method of calculation for inter-limb asymmetry.

Table 4. Study results-inter-limb asymmetries in lower-limb strength/power and muscle flexibility.

\begin{tabular}{|c|c|c|c|}
\hline References & Variables of Interest & $\begin{array}{l}\text { Equations for Calculating } \\
\text { Asymmetry }\end{array}$ & Findings \\
\hline Brumitt, Heiderscheit, Manske, et al. [18] & Single-leg hop distance & Low $/$ high $\times 100(\%)$ & $\begin{array}{l}10 \% \text { hop asymmetry associated with greater } \\
\text { risk of foot and ankle injury in female } \\
\text { collegiate athletes }(\mathrm{OR}=4.4, p<0.05)\end{array}$ \\
\hline Brumitt, Mattocks, Loew and Lentz [10] & Single-leg hop distance & Not reported & $\begin{array}{l}10 \% \text { hop asymmetry not associated with } \\
\text { injury in female collegiate volleyball players } \\
(p>0.05)\end{array}$ \\
\hline Read, Oliver, Croix, et al. [31] & $\begin{array}{l}\text { Biomechanics in single-leg CMJ } \\
\text { and hop }\end{array}$ & $($ Low - high $) /$ high $\times 100(\%)$ & $\begin{array}{l}\text { Single-leg CMJ peak landing vertical GRF } \\
\text { asymmetry }(\mathrm{U} 11-12, \mathrm{OR}=0.90, p=0.04 ; \\
\mathrm{U} 15-16, \mathrm{OR}=0.91, p<0.001) \text { associated with } \\
\text { non-contact lower-limb injury male youth } \\
\text { soccer athletes }\end{array}$ \\
\hline $\begin{array}{l}\text { Fort-Vanmeerhaeghe, Mila-Villarroel, } \\
\text { Pujol-Marzo, et al. [22] }\end{array}$ & $\begin{array}{l}\text { Single-leg CMJ height, } \\
\text { hop distance }\end{array}$ & $($ High - low $) /$ high $\times 100(\%)$ & $\begin{array}{l}\text { Non-injured young team-sport athletes } \\
\text { showed lower single-leg CMJ height } \\
\text { asymmetry }(p=0.00) \text { vs. injured athletes }\end{array}$ \\
\hline Warren, Lininger, Smith, et al. [35] & $\begin{array}{l}\text { Single-leg hop, triple-hop, and } \\
\text { crossover hop distance }\end{array}$ & $\begin{array}{l}\text { Absolute difference between } \\
\text { limbs }\end{array}$ & $\begin{array}{l}\text { Triple-hop distance asymmetry (OR ( }>12 \text { vs. } \\
\leq 12 \mathrm{~cm})=7.31, p<0.05 \text { ) associated with } \\
\text { greater risk of lower-body (lower limb and } \\
\text { spine) injury in female collegiate athletes }\end{array}$ \\
\hline Paterno, Schmitt, Ford, et al. [6] & $\begin{array}{l}\text { Internal knee extensor moment } \\
\text { at initial contact in drop } \\
\text { vertical jump }\end{array}$ & Not reported & $\begin{array}{l}\text { Internal knee extensor moment asymmetry at } \\
\text { initial contact }(\mathrm{OR}=3.3, p \text { not reported) } \\
\text { associated with second ACL injury in young } \\
\text { athletes with ACL reconstruction and } \\
\text { returning to sport }\end{array}$ \\
\hline Sieland, Krause, Kalo, et al. [33] & $\begin{array}{l}\text { Single-leg CMJ height and } \\
\text { hop distance }\end{array}$ & $\begin{array}{l}\text { Dominant/non-dominant } \times \\
100(\%)\end{array}$ & $\begin{array}{l}\text { Injured male youth soccer athletes showed } \\
\text { greater single-leg hop distance asymmetry vs. } \\
\text { non-injured athletes ( } p=0.027 \text { adjusted } \\
\text { for age) }\end{array}$ \\
\hline Steidl-Muller, Hildebrandt, Muller, et al. [34] & $\begin{array}{l}\text { Single-leg CMJ height, } \\
\text { isometric/isokinetic knee } \\
\text { extension strength }\end{array}$ & $\begin{array}{l}\text { Dominant/non-dominant } \times \\
100(\%)\end{array}$ & $\begin{array}{l}\text { Isometric knee extension strength asymmetry } \\
\text { (Wald }=7.08, p<0.01 \text { ) associated with } \\
\text { traumatic injury in } 10-14 \text { years ski racers }\end{array}$ \\
\hline De Blaiser, Roosen, Willems, et al. [21] & $\begin{array}{l}\text { Isometric strength in } \\
\text { hip abduction }\end{array}$ & Weaker/stronger × $100(\%)$ & $\begin{array}{l}\text { Hip abduction strength asymmetry } \\
\text { associated with acute lower-limb injury in } \\
\text { collegiate physical education students (HR = } \\
0.941, p=0.007)\end{array}$ \\
\hline Hietamo, Pasanen, Leppänen, et al. [25] & Isometric hip abductor strength & Not reported & $\begin{array}{l}\text { Hip abductor strength asymmetry }(\mathrm{HR}=1.44, \\
p<0.05) \text { associated with greater risk of acute } \\
\text { ankle injury in young athletes }\end{array}$ \\
\hline Markovic, Šarabon, Pausic and Hadžić [11] & Isometric hip adductor torque & Left/right & $\begin{array}{l}\text { Adductor strength asymmetry }(p=0.09) \text { not } \\
\text { associated with groin injury in professional } \\
\text { soccer players }\end{array}$ \\
\hline Fousekis, Tsepis, Poulmedis, et al. [14] & $\begin{array}{l}\text { Isokinetic concentric and } \\
\text { eccentric hamstring and } \\
\text { quadriceps strength; } \\
\text { quadriceps flexibility }\end{array}$ & $\begin{array}{l}\text { Strength: not reported } \\
\text { Flexibility: right - left }\end{array}$ & $\begin{array}{l}\geq 15 \% \text { eccentric hamstring strength } \\
\text { asymmetry }(\mathrm{OR}=3.88, p=0.03) \text { associated } \\
\text { with greater risk of hamstring strain in } \\
\text { professional soccer players } \\
\geq 15 \% \text { eccentric quadriceps strength } \\
\text { asymmetry (OR }=5.02, p=0.06), \geq 6^{\circ} \\
\text { quadriceps flexibility asymmetry }(\mathrm{OR}=4.98, \\
p=0.08) \text { associated with greater risk of } \\
\text { quadriceps strain in professional } \\
\text { soccer players }\end{array}$ \\
\hline Fousekis, Tsepis and Vagenas [15] & $\begin{array}{l}\text { Isokinetic concentric and } \\
\text { eccentric strength in ankle } \\
\text { dorsal and plantar flexors; } \\
\text { ankle flexibility }\end{array}$ & $\begin{array}{l}\text { Strength: not reported } \\
\text { Flexibility: right }- \text { left }\end{array}$ & $\begin{array}{l}\geq 15 \% \text { asymmetry in eccentric ankle flexion } \\
\text { strength }(\mathrm{OR}=8.88, p=0.005) \text { associated } \\
\text { with greater risk of ankle sprain in } \\
\text { professional soccer players }\end{array}$ \\
\hline Knapik, Bauman, Jones, et al. [3] & $\begin{array}{l}\text { Isokinetic knee flexor strength; } \\
\text { hip extensor flexibility }\end{array}$ & Right/left & $\begin{array}{l}\text { More injuries occurred in female collegiate } \\
\text { athletes when } \\
\text { (1) right }>\text { left knee flexor strength }\left(180^{\circ} / \mathrm{s}\right) \\
\text { by } 15 \%(\text { Chi square, } 9.5 ; p=0.005) \\
\text { (2) right }>\text { left hip extensor flexibility by } 15 \% \\
\text { (chi square, } 10.71 ; p<0.001)\end{array}$ \\
\hline
\end{tabular}


To examine the inter-limb asymmetry in lower-limb muscle flexibility (Table 4), two studies used the absolute difference in range of motion $\left({ }^{\circ}\right)$ between the two sides [14,15]; the other study quantified the inter-limb asymmetry as a percentage (right divided by left) of difference between the two sides [3].

For inter-limb asymmetry in dynamic balance (Table 5), most studies used the absolute difference $(\mathrm{cm})$ of reach distance (at each reach direction) between the two sides. Only one study normalized the reach distance to leg length (leg length\%) and quantified both the absolute $(\mathrm{cm})$ and normalized (\%) inter-limb asymmetry [13].

Table 5. Study results-inter-limb asymmetries in dynamic balance.

\begin{tabular}{|c|c|c|c|}
\hline References & Variables of Interest & Calculation for Asymmetry & Findings \\
\hline Brumitt, Nelson, Duey, et al. [13] & $\begin{array}{l}\text { ANT, PM, and PL reach } \\
\text { distance asymmetry }\end{array}$ & $\begin{array}{l}\text { Absolute difference and the } \\
\text { normalized difference to leg } \\
\text { length }\end{array}$ & $\begin{array}{l}\text { No association between asymmetries and } \\
\text { injury in male collegiate basketball players } \\
(\mathrm{RR}=0.9-1.2, p>0.05)\end{array}$ \\
\hline Brumitt, Sikkema, Mair, et al. [19] & $\begin{array}{l}\text { ANT, PM, and PL reach } \\
\text { distance asymmetry }\end{array}$ & Not reported & $\begin{array}{l}\text { No association between asymmetries and } \\
\text { injury in collegiate athletes (no cut-off value } \\
\text { in ROC curve) }\end{array}$ \\
\hline Butler, Lehr, Fink, et al. [20] & $\begin{array}{l}\text { ANT, PM, and PL reach } \\
\text { distance asymmetry }\end{array}$ & Absolute difference & $\begin{array}{l}\text { No association between asymmetries and } \\
\text { injury (no cut-off value in ROC curve) in } \\
\text { collegiate American football players }\end{array}$ \\
\hline De Blaiser, Roosen, Willems, et al. [21] & $\begin{array}{l}\text { ANT, PM, and PL reach } \\
\text { distance asymmetry }\end{array}$ & Absolute difference & $\begin{array}{l}\text { No association between asymmetries and } \\
\text { injury in university physical education } \\
\text { students }(p>0.05)\end{array}$ \\
\hline Gonell, Romero and Soler [23] & $\begin{array}{l}\text { ANT, PM, and PL reach } \\
\text { distance asymmetry }\end{array}$ & Absolute difference & $\begin{array}{l}\geq 4 \mathrm{~cm} \text { PM reach distance asymmetry } \\
(\mathrm{OR}=3.86, p=0.001) \text { associated with greater } \\
\text { risk of lower-limb injury in male soccer } \\
\text { players }\end{array}$ \\
\hline Hartley, Hoch and Boling [24] & $\begin{array}{l}\text { ANT, PM, and PL reach } \\
\text { distance asymmetry }\end{array}$ & Absolute difference & $\begin{array}{l}\text { No association between asymmetries and } \\
\text { ankle sprain injury in female collegiate } \\
\text { athletes }(p>0.05)\end{array}$ \\
\hline Lai, Wang, Chen, et al. [26] & $\begin{array}{l}\text { ANT, PM, and PL reach } \\
\text { distance asymmetry }\end{array}$ & Absolute difference & $\begin{array}{l}\text { No association between asymmetries and } \\
\text { lower-limb injury in collegiate athletes } \\
(p>0.05)\end{array}$ \\
\hline Lisman, Hildebrand, Nadelen and Leppert [12] & $\begin{array}{l}\text { ANT, PM, and PL reach } \\
\text { distance asymmetry }\end{array}$ & Absolute difference & $\begin{array}{l}\text { No association between asymmetries and } \\
\text { lower-limb injury in high school athletes } \\
(p>0.05)\end{array}$ \\
\hline Luedke, Geisthardt and Rauh [27] & $\begin{array}{l}\text { ANT, PM, PL, and COM } \\
\text { reach distance asymmetry }\end{array}$ & Absolute difference & $\begin{array}{l}\text { No association between asymmetries and } \\
\text { lower-limb or lower-back injury in collegiate } \\
\text { American football players }(p>0.05)\end{array}$ \\
\hline Manoel, Xixirry, Soeira, et al. [28] & $\begin{array}{l}\text { ANT, PM, and PL reach } \\
\text { distance asymmetry }\end{array}$ & Absolute difference & $\begin{array}{l}\text { No association between asymmetries and } \\
\text { ankle injury in professional male soccer } \\
\text { players }(p>0.05)\end{array}$ \\
\hline Nakagawa, dos Santos, Lessi, et al. [29] & $\begin{array}{l}\text { ANT, PM, and PL reach } \\
\text { distance asymmetry }\end{array}$ & Absolute difference & $\begin{array}{l}\geq 4.08 \mathrm{~cm} \text { PL reach distance asymmetry } \\
(\mathrm{OR}=5.46, p<0.001) \text { associated with } \\
\text { patellofemoral pain in male military recruits }\end{array}$ \\
\hline Plisky, Rauh, Kaminski and Underwood [4] & $\begin{array}{l}\text { ANT, PM, and PL reach } \\
\text { distance asymmetry }\end{array}$ & Absolute difference & $\begin{array}{l}\geq 4 \mathrm{~cm} \text { PM reach distance asymmetry } \\
(\mathrm{OR}=2.3, p<0.05) \text { associated with greater } \\
\text { risk of lower-limb injury in high-school } \\
\text { basketball players }\end{array}$ \\
\hline Read, Oliver, Myer, et al. [30] & $\begin{array}{l}\text { ANT reach } \\
\text { distance asymmetry }\end{array}$ & Absolute difference & $\begin{array}{l}\text { ANT reach distance asymmetry associated } \\
\text { with non-contact lower-limb injury in male } \\
\text { youth soccer players (pre-PHV: OR }=0.94 \text {, } \\
p<0.05 \text {; circa-PHV: OR }=1.05, p<0.05 \text { ) }\end{array}$ \\
\hline Ruffe, Sorce, Rosenthal and Rauh [32] & $\begin{array}{l}\text { ANT, PM, and PL reach } \\
\text { distance asymmetry }\end{array}$ & Absolute difference & $\begin{array}{l}\geq 4 \mathrm{~cm} \text { PM reach distance asymmetry } \\
(\mathrm{OR}=5.05, p=0.02) \text { associated with greater } \\
\text { risk of lower-limb or low back injury in } \\
\text { young cross-country athletes }\end{array}$ \\
\hline Smith, Chimera and Warren [9] & $\begin{array}{l}\text { ANT, PM, and PL reach } \\
\text { distance asymmetry }\end{array}$ & Absolute difference & $\begin{array}{l}\geq 4 \mathrm{~cm} \text { ANT reach distance asymmetry } \\
(\mathrm{OR}=2.20, p=0.03) \text { associated with greater } \\
\text { risk of non-contact injury in } \\
\text { collegiate athletes }\end{array}$ \\
\hline
\end{tabular}

ANT, anterior; PM, posteromedial; PL, posterolateral; RR, relative risk; ROC, receiver operating characteristic; OR odds ratio; COM, composite; $\mathrm{PHV}$, peak height velocity. 


\section{Discussion}

The main purpose of this systematic review was to summarize and synthesize findings of studies examining whether inter-limb asymmetries in lower-limb strength/power, dynamic balance, and muscle flexibility can predict sport injury. Overall, mixed findings have been reported, and it is difficult to make a clear statement about the validity of using inter-limb asymmetry to predict sport injury. Findings were highly inconsistent due to the variations in research methodology across studies. A number of considerations (difference in tests, participant characteristics, definition of injury, and ways of calculating asymmetries) are required to infer recommendations for future research and practical application. These considerations and the potential influence on research findings will be discussed in this section.

\subsection{Tests/Tasks}

Inter-limb asymmetry in each capacity (lower-limb strength/power, flexibility, and dynamic balance) has been assessed with a variety of tests. It is difficult to compare the amount of inter-limb asymmetry generated from different tests. Even using the same test, it is difficult to compare the amount of inter-limb asymmetry between studies using different parameters (e.g., jump height vs. peak ground reaction force during landing in unilateral $\mathrm{CMJ})$. The variation in selection of tests may result in inconsistent findings, especially when using the cut-off values for injury prediction. For example, $\geq 15 \%$ inter-limb asymmetry in isokinetic strength of knee extensor, knee flexor [14], and ankle flexor [15] have been associated with greater risk of injury; however, this association was not shown when using $\geq 15 \%$ inter-limb asymmetry in isometric hip strength $[11,21]$ or unilateral jump tests $[10,18]$ to predict injury. Therefore, before comparing findings between studies, it is important to consider the difference between tests (and parameters).

A number of studies assessed inter-limb asymmetries in lower-limb strength/power using isometric/isokinetic strength tests and unilateral/bilateral jump tests. However, the isometric and isokinetic strength tests may not be the optimal tests for sports characterized by quick muscle actions involving stretch-shortening cycle [36]. Instead, jump tests are recommended for the assessment of lower-limb strength/power because of the required stretch-shortening cycle and high-rate force production [36]. Especially, unilateral jumps are recommended because the movements of unilateral jumps rely on the force generated from one side, and the performance of the dominant and non-dominant side separately were more indicative for the difference between the two sides [37]. Moreover, the single-leg drive/support is common in movements including sprint, jump, jump landing, change of direction, and kick, which also supports the use of unilateral jump tests for the assessment of inter-limb asymmetry in lower-limb strength/power. Furthermore, unilateral jump landing was often associated with the common mechanism of non-contact injuries such as the ACL tear [38]. Five of the six included studies using unilateral jump tests to assess inter-limb asymmetry have reported significant association between asymmetry and sport injury $[18,22,31,33,35]$, which indicates that the inter-limb asymmetries in unilateral jump performance could be a valid predictor for sport injury.

Lower-limb muscle flexibility has been commonly evaluated using the range of motion of lower limb joints (ankle, knee, and hip). A greater range of motion of the joint indicates better flexibility of related muscles [39]. The inter-limb asymmetry in muscle flexibility has been usually assessed by quantifying the difference in range of motion of the joint between the two sides. Although using the same parameter (range of motion), inter-limb asymmetries in flexibility have been assessed in different joints including the ankle $[3,14,15]$, knee [3,15], and hip [3], and few findings are available regarding each joint. More studies are needed to examine the relationship between inter-limb asymmetry in lower-limb muscle flexibility and sport injury, due to the limited number of studies in the current literature.

Inter-limb asymmetry in dynamic balance has been commonly assessed with the SEBT and Y balance test. However, there is a lack of a standardized protocol outlining the operation of the SEBT [40]. The variation across protocols includes whether the reaching 
foot is allowed to touch the floor, how much movement the standing foot is allowed, and the specific position of the standing foot [41]; all of these variations may affect the findings. Therefore, there is a need to develop a standardized and universal protocol for the SEBT to allow accurate comparison between studies. Although the $\mathrm{Y}$ balance test has been developed to improve the standardization of the SEBT with the use of a device composed of three pieces extending in the anterior, posteromedial, and posterolateral directions [41], some of the problems (e.g., how much movement the standing foot is allowed) still exist.

\subsection{Participant Characteristics}

Participants with different characteristics have been included. First, sex may be an important factor affecting the risk of sport injury. A systematic review focusing on child and adolescent sport has reported that boys are generally at greater risk of sport injury compared with girls [42]. However, girls showed greater risk of injury compared to boys in specific sports including soccer, basketball, and baseball, which might be related to the physiological and anatomical characteristics of girls [42]. Moreover, studies have demonstrated a higher rate of specific injuries such as ACL ruptures in females compared to males $[43,44]$. Although findings are not consistent, it is clear that the potential effects of sex on injury risk should be considered when evaluating the relationship between interlimb asymmetry in lower-limb functional performance and sport injury. However, few studies have addressed the difference between sexes when examining this relationship. Only one study has reported that $>10 \%$ inter-limb asymmetry in single-leg hop distance indicates greater risk of sport injury in females while not in males [18], which implies the importance of addressing the difference between sexes when predicting sport injury using inter-limb asymmetry in jump performance.

Athletes from a wide range of sports have been included. Whether the relationship between inter-limb asymmetry and sport injury can be affected by the difference between sports has not been addressed. As each sport may have a different speed/strength requirement, future research should pay attention to the difference of sporting background between participants. Further, there is a lack of studies focusing on laterally dominant (or asymmetric) sports such as fencing. It is not clear whether or not the inter-limb asymmetry in laterally dominant sports is formed to meet the physical demands of these sports and as such are important for injury prevention. For example, Gray, Aginsky, Derman et al. [45] has reported that the side-to-side asymmetry in the abdominal muscles in cricket fast bowlers is likely an adaptation required to perform specific tasks in this sport, and it may not always be detrimental to athletes.

Exposure time and previous injury of the participants may also influence the findings. Greater volume of exposure to sport has been associated with increased risk of injury $[42,46,47]$. Athletes with previous injury also showed greater risk of injury in sport activities [47]. However, most injury prediction models failed to control for the potential influence of these two factors. We recommend including the exposure time to sport and previous injury as covariates when examining the association between inter-limb asymmetry and sport injury.

Risk of sport injury has been reported increasing with age in pediatric-age athletes $(<18$ y old) $[42,46,48]$, which may influence the findings generated from pediatric-age athletes. Only four studies have focused on pediatric-age athletes: three studies examined the association between inter-limb asymmetry in lower-limb strength/power and sport injury [22,31,34]; and one study examined the association between inter-limb asymmetry in dynamic balance and sport injury [30]. Among these four studies, only one study has addressed the effects of growth and maturation, reporting a difference between growth stages (pre-PHV vs. circa-PHV vs. post-PHV) in the validity of using inter-limb asymmetry in dynamic balance to predict non-contact lower-limb injury [30]. It is suggested that more studies should focus on pediatric-age athletes, and further examine the effects of age (or the progress of growth and maturation) on the relationship between inter-limb asymmetry and sport injury. 


\subsection{Definition of Injury}

Injury has been variously defined across studies, due to the differences in the mechanism (contact vs. non-contact injury) of injury, duration of time loss (from sport activities), and included body part of injury, which may contribute to the inconsistency of findings. Although contact injuries account for the majority of sport injuries $[49,50]$, some noncontact injuries (e.g., ligament sprains and muscle strains) are the most common sport injuries [50,51]. Further, non-contact injuries are often associated with modifiable risk factors including neuromuscular disorders [23]. Most studies only included lower-limb injuries for the body part of injury, while some studies included injuries occurred to any part of the body. We recommend associating inter-limb asymmetries (in lower-limb strength/power, dynamic balance, and muscle flexibility) to injuries occurring to the lower limbs, since these tests mainly examine physical capacity of the lower limbs. Ten of the fourteen included studies examining the relationship between lower-limb strength/power and injury have focused on non-contact lower-limb injuries, and eight of them have reported a significant association $[6,14,15,18,21,25,31,35]$. Based on these findings and the above-mentioned perspective, it is suggested that future investigations should focus on non-contact lower-limb injuries.

Most studies have included injuries leading to time loss (from sport activities) of one day or longer ( $\geq 1$ day), while there is no uniform requirement of the duration. Moreover, time loss was not always a requirement of injury in previous studies. The difference in the duration of time loss in the definition of injury will likely impact the injury rate and related findings regarding the association between inter-limb asymmetry and sport injury.

In addition, the duration of follow-up (observation for injury) varies across studies, which may also influence the findings. Some studies prospectively traced the participants for injury for one or two seasons; however, the specific duration of a season was not clearly defined. Future studies should clearly define the duration of the follow-up.

\subsection{Calculation of Asymmetries}

A variety of equations have been employed to calculate inter-limb asymmetry in lowerlimb strength/power, which may contribute to the inconsistency of findings regarding the association between inter-limb asymmetry and sport injury. The variety of equations makes it difficult to compare the given values of inter-limb asymmetry even in the same test. For example, as a widely suggested cut-off value, $15 \%$ inter-limb asymmetry in strength/power may not represent the same amount of asymmetry in studies using different equations (to calculate asymmetry), due to the fact that different equations may result in different amounts of asymmetries. Therefore, it is important to pay attention to the equation used for calculating inter-limb asymmetry in lower-limb strength/power when utilizing previously reported cut-off values for injury prediction.

Most studies using the dynamic balance test have quantified the inter-limb asymmetry using the absolute difference in reach distances $(\mathrm{cm})$ measured in the SEBT and Y balance test between the two sides. This may also contribute to the inconsistency of findings due to the influence of leg length. Research has reported that the reach distances in SEBT are correlated with leg length, and a greater leg length is associated with farther reach distance [52]. When using the cut-off value (e.g., $4 \mathrm{~cm}$ inter-limb asymmetry) to predict sport injury, the influence of leg length should be a consideration. Gribble and Hertel [52] suggested that the reach distance measured in the SEBT and Y balance test should be normalized to leg length (leg length\%) to ensure the accuracy of comparison between participants or studies. We recommend future research include both the absolute and normalized (to leg length) asymmetry when examining the relationship between interlimb asymmetry in dynamic balance (measured with the SEBT and Y balance test) and sport injury. In addition, the amount of inter-limb asymmetry may change during the period of follow-up, which may also influence the results. Longitudinal data are needed to monitor the change in the amount of inter-limb asymmetry during the follow-up. In data analyses, the amount of inter-limb asymmetry has been reported with a variable nature and 
the standard deviation is usually close to or even greater than the mean [53]. Research has suggested that the inter-limb asymmetry should be greater than the intra-limb variation (quantified using the coefficient of variation) to make it effective [54]. Moreover, the ICC should be reported to evaluate the reliability of data for each leg before calculating the inter-limb asymmetry [4,22].

\subsection{Limitations}

There are several limitations in this systematic review. Firstly, it is difficult to draw a conclusion whether inter-limb asymmetry in lower-limb functional performance (strength/power, dynamic balance, flexibility) can predict sport injury, because of the influence of multiple variables (tests/tasks, participant characteristics, definition of injury, calculation of asymmetries). Thus, we discussed the variables which may contribute to the inconsistency of previous findings to provide suggestions/directions for future research and practical application. In addition, although 28 studies are included in this systematic review, there is still a limited number of studies available when controlling for each variable. More investigations are required to better determine the association between inter-limb asymmetry in lower-limb functional performance and sport injury.

\section{Conclusions and Future Directions}

In summary, findings regarding the relationship between inter-limb asymmetry in lower-limb functional performance and sport injury are highly inconsistent, which may be attributed to the variation in tests/parameters, participant characteristics (sex, sporting background, exposure time, previous injury, age), definition of injury, and ways of calculating asymmetry between studies. To make a clear statement on this relationship (inter-limb asymmetry and sport injury) is difficult. To predict sport injury based on previous findings, the effects of the above-mentioned factors (tests/parameters, participant characteristics, definition of injury, ways of calculating asymmetry) should be considered.

When considering the selection of tests for the assessment of inter-limb asymmetry in lower-limb strength/power, we recommend using unilateral jump tests because these movements closely reflect real-life sporting demands. To assess inter-limb asymmetry in dynamic balance, future study needs to develop a standardized protocol for the SEBT and Y balance test to allow accurate comparison between studies.

Future study also needs to address the role of sex when examining the association between inter-limb asymmetry in lower-limb functional performance and sport injury, and the potential effects of exposure time to sport and previous injury of participants should also be controlled for. More studies are needed, which focus on pediatric-age athletes, and the influence of age on this relationship (asymmetry and injury) needs further investigation. Finally, future research needs to examine this relationship in asymmetrical (laterally-dominant) sports.

Author Contributions: Conceptualization, Y.G. and D.E.R.W.; methodology, Y.G., S.S.D.B., J.T., Q.J. and D.E.R.W.; validation, S.S.D.B., J.T., Q.J. and D.E.R.W.; formal analysis, Y.G. and N.W.; investigation, Y.G. and N.W.; resources, Y.G. and D.E.R.W.; data curation, Y.G. and D.E.R.W.; writingoriginal draft preparation, Y.G.; writing-review and editing, Y.G., S.S.D.B., J.T., Q.J., N.W. and D.E.R.W.; supervision, S.S.D.B. and D.E.R.W. All authors have read and agreed to the published version of the manuscript.

Funding: This research received no external funding.

Conflicts of Interest: The authors declare no conflict of interest.

\section{References}

1. Bishop, C.; Turner, A.; Read, P. Effects of inter-limb asymmetries on physical and sports performance: A systematic review. J. Sports Sci. 2018, 36, 1135-1144. [CrossRef]

2. Hodges, S.J.; Patrick, R.J.; Reiser, R.F. Effects of fatigue on bilateral ground reaction force asymmetries during the squat exercise. J. Strength Cond. Res. 2011, 25, 3107-3117. [CrossRef] 
3. Knapik, J.J.; Bauman, C.L.; Jones, B.H.; Harris, J.M.; Vaughan, L. Preseason strength and flexibility imbalances associated with athletic injuries in female collegiate athletes. Am. J. Sports Med. 1991, 19, 76-81. [CrossRef] [PubMed]

4. Plisky, P.J.; Rauh, M.J.; Kaminski, T.W.; Underwood, F.B. Star Excursion Balance Test as a predictor of lower extremity injury in high school basketball players. J. Orthop. Sports Phys. Ther. 2006, 36, 911-919. [CrossRef]

5. Ford, K.R.; Myer, G.D.; Hewett, T.E. Valgus knee motion during landing in high school female and male basketball players. Med. Sci. Sports Exerc. 2003, 35, 1745-1750. [CrossRef] [PubMed]

6. Paterno, M.V.; Schmitt, L.C.; Ford, K.R.; Rauh, M.J.; Myer, G.D.; Huang, B.; Hewett, T.E. Biomechanical Measures During Landing and Postural Stability Predict Second Anterior Cruciate Ligament Injury After Anterior Cruciate Ligament Reconstruction and Return to Sport. Am. J. Sports Med. 2010, 38, 1968-1978. [CrossRef]

7. Bell, D.R.; Sanfilippo, J.L.; Binkley, N.; Heiderscheit, B.C. Lean mass asymmetry influences force and power asymmetry during jumping in collegiate athletes. J. Strength Cond. Res. 2014, 28, 884-891. [CrossRef] [PubMed]

8. Gray, G.W. Lower Extremity Functional Profile; Wynn Marketing, Incorporated: Adrian, MI, USA, 1995.

9. Smith, C.A.; Chimera, N.J.; Warren, M. Association of y balance test reach asymmetry and injury in division I athletes. Med. Sci. Sports Exerc. 2015, 47, 136-141. [CrossRef]

10. Brumitt, J.; Mattocks, A.; Loew, J.; Lentz, P. Preseason Functional Performance Test Measures Are Associated With Injury in Female College Volleyball Players. J. Sport Rehabil. 2020, 29, 320-325. [CrossRef] [PubMed]

11. Markovic, G.; Šarabon, N.; Pausic, J.; Hadžić, V. Adductor Muscles Strength and Strength Asymmetry as Risk Factors for Groin Injuries among Professional Soccer Players: A Prospective Study. Int. J. Environ. Res. Public Health 2020, 17, 4946. [CrossRef]

12. Lisman, P.; Hildebrand, E.; Nadelen, M.; Leppert, K. Association of Functional Movement Screen and Y-Balance Test Scores With Injury in High School Athletes. J. Strength Cond. Res. 2019, 35, 1930-1938. [CrossRef] [PubMed]

13. Brumitt, J.; Nelson, K.; Duey, D.; Jeppson, M.; Hammer, L. Preseason Y Balance Test Scores are not associated with noncontact time-loss lower quadrant injury in male collegiate basketball players. Sports 2019, 7, 4. [CrossRef] [PubMed]

14. Fousekis, K.; Tsepis, E.; Poulmedis, P.; Athanasopoulos, S.; Vagenas, G. Intrinsic risk factors of non-contact quadriceps and hamstring strains in soccer: A prospective study of 100 professional players. Br. J. Sports Med. 2011, 45, 709-714. [CrossRef] [PubMed]

15. Fousekis, K.; Tsepis, E.; Vagenas, G. Intrinsic Risk Factors of Noncontact Ankle Sprains in Soccer: A Prospective Study on 100 Professional Players. Am. J. Sports Med. 2012, 40, 1842-1850. [CrossRef] [PubMed]

16. Moher, D.; Liberati, A.; Tetzlaff, J.; Altman, D.G. Preferred reporting items for systematic reviews and meta-analyses: The PRISMA statement. Int. J. Surg. 2010, 8, 336-341. [CrossRef]

17. Wells, G.A.; Shea, B.; O'connell, D.; Peterson, J.; Welch, V.; Losos, M.; Tugwell, P. The Newcastle-Ottawa Scale (NOS) for Assessing the Quality of Nonrandomised Studies in Meta-Analyses; Ottawa Health Research Institute: Ottawa, ON, Canada, 1999.

18. Brumitt, J.; Heiderscheit, B.C.; Manske, R.C.; Niemuth, P.E.; Rauh, M.J. Lower Extremity Functional Tests and Risk of Injury in Division III Collegiate Athletes. Int. J. Sports Phys. Ther. 2013, 8, 216-227. [PubMed]

19. Brumitt, J.; Sikkema, J.; Mair, S.; Zita, C.; Wilson, V.; Petersen, J. Preseason Y Balance Test Scores are Not Associated With a Lower Quadrant Sports Injury in a Heterogeneous Population of Division III Collegiate Athletes. Int. J. Athl. Ther. Train. 2020, 25, 68-75. [CrossRef]

20. Butler, R.J.; Lehr, M.E.; Fink, M.L.; Kiesel, K.B.; Plisky, P.J. Dynamic balance performance and noncontact lower extremity injury in college football players: An initial study. Sports Health 2013, 5, 417-422. [CrossRef]

21. De Blaiser, C.; Roosen, P.; Willems, T.; De Bleecker, C.; Vermeulen, S.; Danneels, L.; De Ridder, R. The role of core stability in the development of non-contact acute lower extremity injuries in an athletic population: A prospective study. Phys. Ther. Sport 2021, 47, 165-172. [CrossRef]

22. Fort-Vanmeerhaeghe, A.; Mila-Villarroel, R.; Pujol-Marzo, M.; Arboix-Alio, J.; Bishop, C. Higher Vertical Jumping Asymmetries and Lower Physical Performance are Indicators of Increased Injury Incidence in Youth Team-Sport Athletes. J. Strength Cond. Res. 2020. Publish ahead of print.

23. Gonell, A.C.; Romero, J.a.P.; Soler, L.M. Relationship between the Y balance test scores and soft tissue injury incidence in a soccer team. Int. J. Sports Phys. Ther. 2015, 10, 955-966.

24. Hartley, E.M.; Hoch, M.C.; Boling, M.C. Y-balance test performance and BMI are associated with ankle sprain injury in collegiate male athletes. J. Sci. Med. Sport 2018, 21, 676-680. [CrossRef]

25. Hietamo, J.; Pasanen, K.; Leppänen, M.; Steffen, K.; Kannus, P.; Heinonen, A.; Mattila, V.; Parkkari, J. Association between lower extremity muscle strength and acute ankle injury in youth team-sports athletes. Phys. Ther. Sport 2021, 48, $188-195$.

26. Lai, W.C.; Wang, D.A.; Chen, J.B.; Vail, J.; Rugg, C.M.; Hame, S.L. Lower Quarter Y-Balance Test Scores and Lower Extremity Injury in NCAA Division I Athletes. Orthop. J. Sports Med. 2017, 5, 2325967117723666. [CrossRef] [PubMed]

27. Luedke, L.E.; Geisthardt, T.W.; Rauh, M.J. Y-Balance Test Performance Does Not Determine Non-Contact Lower Quadrant Injury in Collegiate American Football Players. Sports 2020, 8, 27. [CrossRef]

28. Manoel, L.S.; Xixirry, M.G.; Soeira, T.P.; Saad, M.C.; Riberto, M. Identification of Ankle Injury Risk Factors in Professional Soccer Players Through a Preseason Functional Assessment. Orthop. J. Sports Med. 2020, 8, 2325967120928434. [CrossRef] [PubMed]

29. Nakagawa, T.H.; Dos Santos, A.F.; Lessi, G.C.; Petersen, R.S.; Silva, R.S. Y-Balance Test Asymmetry and Frontal Plane Knee Projection Angle During Single-leg squat as Predictors of Patellofemoral Pain in Male Military Recruits. Phys. Ther. Sport 2020, 44, 121-127. [CrossRef] [PubMed] 
30. Read, P.J.; Oliver, J.L.; Myer, G.D.; Farooq, A.; De Ste Croix, M.; Lloyd, R.S. Utility of the anterior reach Y-BALANCE test as an injury risk screening tool in elite male youth soccer players. Phys. Ther. Sport 2020, 45, 103-110. [CrossRef]

31. Read, P.J.; Oliver, J.L.; Croix, M.; Myer, G.D.; Lloyd, R.S. A prospective investigation to evaluate risk factors for lower extremity injury risk in male youth soccer players. Scand. J. Med. Sci. Sports 2018, 28, 1244-1251. [CrossRef]

32. Ruffe, N.J.; Sorce, S.R.; Rosenthal, M.D.; Rauh, M.J. Lower quarter-and upper quarter Y balance tests as predictors of runningrelated injureis in high school cross-country runners. Int. J. Sports Phys. Ther. 2019, 14, 695-706. [CrossRef]

33. Sieland, J.; Krause, F.; Kalo, K.; Wilke, J.; Vogt, L.; Banzer, W.; Niederer, D. Injuries and functional performance status in young elite football players: A prospective 2-year monitoring. J. Sports Med. Phys. Fit. 2020, 60, 1363-1370. [CrossRef]

34. Steidl-Muller, L.; Hildebrandt, C.; Muller, E.; Fink, C.; Raschner, C. Limb symmetry index in competitive alpine ski racers: Reference values and injury risk identification according to age-related performance levels. J Sport Health Sci. 2018, 7, 405-415. [CrossRef] [PubMed]

35. Warren, M.; Lininger, M.R.; Smith, C.A.; Copp, A.J.; Chimera, N.J. Association of Functional Screening Tests and Noncontact Injuries in Division I Women Student-Athletes. J. Strength Cond. Res. 2020, 34, 2302-2311. [CrossRef] [PubMed]

36. Impellizzeri, F.M.; Rampinini, E.; Maffiuletti, N.; Marcora, S.M. A vertical jump force test for assessing bilateral strength asymmetry in athletes. Med. Sci. Sports Exerc. 2007, 39, 2044-2050. [CrossRef]

37. Benjanuvatra, N.; Lay, B.S.; Alderson, J.A.; Blanksby, B.A. Comparison of ground reaction force asymmetry in one-and two-legged countermovement jumps. J. Strength Cond. Res. 2013, 27, 2700-2707. [CrossRef] [PubMed]

38. Heil, J.; Loffing, F.; Büsch, D. The Influence of Exercise-Induced Fatigue on Inter-Limb Asymmetries: A Systematic Review. Sports Med. Open 2020, 6, 39. [CrossRef] [PubMed]

39. Witvrouw, E.; Danneels, L.; Asselman, P.; D’have, T.; Cambier, D. Muscle flexibility as a risk factor for developing muscle injuries in male professional soccer players: A prospective study. Am. J. Sports Med. 2003, 31, 41-46. [CrossRef]

40. Coughlan, G.F.; Fullam, K.; Delahunt, E.; Gissane, C.; Caulfield, B.M. A comparison between performance on selected directions of the star excursion balance test and the Y balance test. J. Athl. Train. 2012, 47, 366-371. [CrossRef]

41. Plisky, P.J.; Gorman, P.P.; Butler, R.J.; Kiesel, K.B.; Underwood, F.B.; Elkins, B. The reliability of an instrumented device for measuring components of the star excursion balance test. N. Am. J. Sports Phys. Ther. 2009, 4, 92.

42. Emery, C.A. Risk factors for injury in child and adolescent sport: A systematic review of the literature. Clin. J. Sport Med. 2003, 13, 256-268. [CrossRef] [PubMed]

43. Dick, R.; Putukian, M.; Agel, J.; Evans, T.A.; Marshall, S.W. Descriptive epidemiology of collegiate women's soccer injuries: National Collegiate Athletic Association Injury Surveillance System, 1988-1989 through 2002-2003. J. Athl. Train. 2007, 42, 278-285.

44. Agel, J.; Arendt, E.A.; Bershadsky, B. Anterior cruciate ligament injury in national collegiate athletic association basketball and soccer: A 13-year review. Am. J. Sports Med. 2005, 33, 524-531. [CrossRef]

45. Gray, J.; Aginsky, K.D.; Derman, W.; Vaughan, C.L.; Hodges, P.W. Symmetry, not asymmetry, of abdominal muscle morphology is associated with low back pain in cricket fast bowlers. J. Sci. Med. Sport 2016, 19, 222-226. [CrossRef]

46. Michaud, P.; Renaud, A.; Narring, F. Sports activities related to injuries? A survey among 9-19 year olds in Switzerland. Inj. Prev. 2001, 7, 41-45. [CrossRef] [PubMed]

47. Emery, C.; Tyreman, H. Sport participation, sport injury, risk factors and sport safety practices in Calgary and area junior high schools. Paediatr. Child Health 2009, 14, 439-444. [CrossRef]

48. Bijur, P.E.; Trumble, A.; Harel, Y.; Overpeck, M.D.; Jones, D.; Scheidt, P.C. Sports and recreation injuries in US children and adolescents. Arch. Pediatr. Adolesc. Med. 1995, 149, 1009-1016. [CrossRef]

49. Bastos, F.N.; Vanderlei, F.M.; Vanderlei, L.C.M.; Júnior, J.N.; Pastre, C.M. Investigation of characteristics and risk factors of sports injuries in young soccer players: A retrospective study. Int. Arch. Med. 2013, 6, 14. [CrossRef]

50. Hootman, J.M.; Dick, R.; Agel, J. Epidemiology of collegiate injuries for 15 sports: Summary and recommendations for injury prevention initiatives. J. Athl. Train. 2007, 42, 311-319. [PubMed]

51. Emery, C.A.; Meeuwisse, W.H.; Mcallister, J.R. Survey of sport participation and sport injury in Calgary and area high schools. Clin. J. Sport Med. 2006, 16, 20-26. [CrossRef]

52. Gribble, P.A.; Hertel, J. Considerations for normalizing measures of the Star Excursion Balance Test. Meas. Phys. Educ. Exerc. Sci. 2003, 7, 89-100. [CrossRef]

53. Bishop, C.; Mccauley, W.; Read, P.; Gonzalo-Skok, O.; Lake, J.P.; Turner, A. Acute effects of repeated sprints on interlimb asymmetries during unilateral jumping. J. Strength Cond. Res. 2019, 35, 2127-2132. [CrossRef]

54. Turner, A.; Brazier, J.; Bishop, C.; Chavda, S.; Cree, J.; Read, P. Data analysis for strength and conditioning coaches: Using excel to analyze reliability, differences, and relationships. Strength Cond. J. 2015, 37, 76-83. [CrossRef] 